\title{
Harvesting desert locusts for food and feed may contribute to crop protection but will not suppress upsurges and plagues
}

\author{
A. van Huis \\ Laboratory of Entomology, Wageningen University E Research, P.O. Box 16, 6700 AA Wageningen, the Netherlands; \\ editor-in-chief@insectsasfoodandfeed.com
}

(C) 2021 Wageningen Academic Publishers

OPEN ACCESS (c) $\underset{\mathrm{BY}}{(\mathrm{O})(\mathrm{NC}}$

EDITORIAL

\begin{abstract}
The desert locust is the most destructive locust species in the world. Locusts differ from grasshoppers in behaviour as they can form hopper bands and swarms. During plagues in the past, locusts have been collected or destroyed by mechanical means. One of the control methods that are being suggested is to collect the locusts for consumption instead of using pesticides. Upsurges and plagues are an ideal opportunity to harvest these insects for food and feed. However, this is unlikely to significantly reduce the population.
\end{abstract}

\section{Introduction}

An editorial last year dealt with insect pests as food and feed (Van Huis, 2020). Among those were locusts. Every time there is an upsurge of locusts, such as the one in 20192021 (FAO, 2021a), the suggestion is often made to eat them instead of using pesticides. In this editorial we will look at whether harvesting locusts as food or feed would help suppress upsurges or plagues. Among the harvesting methods proposed are hand collecting, large sweeping nets, or machines that can suck up the insects.

Before continuing, it is important to outline the difference between locusts and grasshoppers. Locusts are grasshoppers, belonging to the family Acrididae. They differ from grasshoppers in that they can change their behaviour. Locusts are normally solitarious (like grasshoppers), but in crowded conditions they become gregarious (different morphology, colour, and behaviour). When gregarious, the larvae (without wings) march in hopper bands and the adults (with wings) swarm (often hundreds of kilometres a day). FAO (2021b) stated for the desert locust:

An adult can consume roughly its own weight, about 2 grams, in food every day. A one $\mathrm{km}^{2}$-sized swarm of 40 million desert locusts could eat the same amount of food in one day as about 35,000 people. Locust swarms can vary from less than one square kilometre to several hundred square kilometres.
Locusts are a spectacular phenomenon when compared to stemborers, although both may inflict the same amount of damage countrywide. However, locusts destroy the complete yield of several farmers, while stemborers reduce the yields of all farmers.

There are numerous grasshopper species that are collected as food and feed. However, they will not be considered in this editorial. Locusts are reared as food and feed, in particular the migratory locust, Locusta migratoria, but also the desert locust, Schistocerca gregaria. There are companies that specialise in rearing those locust species. However, in this editorial we will not deal with the rearing of locusts but only with the harvesting from nature and whether this could be a control option.

Gregarious desert locusts contain significant proportions of energy, proteins, fats, vitamins and minerals (Kinyuru, 2020). The desert locust ingests phytosterols from its vegetative diet and amplifies and metabolises them into novel derivatives with potential human health benefits (Cheseto et al., 2015). Therefore, the desert locust is a nutritious food source for both humans and animals. 


\section{Important locust species}

The desert locust is the most important locust species due to its ability to migrate over large distances and rapidly increase its numbers. Desert locust plagues can affect up to $20 \%$ (29 million $\mathrm{km}^{2}$ ) of the earth's surface in Africa, the Middle East and south-west Asia. Over 60 countries are intermittently at risk of swarm invasion and breeding.

There are several other important species of locusts throughout the world, such as in Africa the desert locust, the migratory locust (Locusta migratoria migratorioides), the red locust (Nomadacris septemfasciata), and the brown locust (Locustana pardalina). In Australia, we have the Australian plague locust, Chortoicetes terminifera; in South America, the south American locust, Schistocerca cancellate; and in Asia the Oriental migratory locust, Locusta migratoria manilensis, and the Bombay locust, Nomadacris succincta. Some are distributed over several continents, e.g. the desert locust, but also the Italian locust, Calliptamus italicus (western Europe to Central Asia), the Moroccan locust, Dociostaurus maroccanus (north-West Africa to Asia) and tree locusts, Anacridium spp. (Africa, Mediterranean, Near East).

\section{History of mechanical control}

In the $2^{\text {nd }}$ and $1^{\text {st }}$ millennium $\mathrm{BC}$, reports of the capture of desert locusts for consumption, as well as their killing to preclude severe crop damage, are found in letters to Syrian and Assyrian kings (Lanfranchi, 2005). Locust consumption was an elitist habit: in an $8^{\text {th }}$ century BC Neo Assyrian relief on a palace slab there is a representation of the introduction of sets of locusts fixed on spits to a royal banquet. Also in Madagascar, Queen Ranavalona II (1829-1883) ordered servants to collect the locust (Locusta migratoria capito) for food (Decary, 1937).

Before the use of pesticides locusts were controlled by mechanical and cultural control (trampling, beating, burning pastures, digging up egg beds) as mentioned for the brown locust by Price and Brown (2000), and digging trenches, beating and burning for the desert locust (Dobson, 2001). For the Rocky Mountain locust, Melanoplus spretus, which became extinct in the 1890s, there was quite an arsenal of human and horse-drawn equipment to smash, scoop and suck up the locusts (Lockwood, 2004: 49-56). The implements included rotating drums, rollers, wheels, and wooden bars to smash the locusts, and even flame throwers. Digging up egg fields and using trenches as pitfall traps were also common. In Afghanistan, the funds to provide pesticides dried up in 1996 due to civil war (Stride et al., 2003) so mechanical control of the Moroccan locust, used by generations of farmers, was reintroduced.
This technique involved monitoring egg beds in the spring to predict egg hatch, together with the timely mobilisation of communities to dig trenches in front of the advancing bands of hoppers. Between 1996 and 1999, about 30,000 ha of locusts were cleared by this method, resulting in savings on the purchase of insecticide of around US\$ 300,000. However, it was also concluded that that mechanical control alone would probably have been insufficient to manage the annual problem of Moroccan locust.

Modern mechanical methods are experimental in nature, such as laser irradiation (Yao et al., 2009a,b) or led light (Lysakov et al., 2019).

\section{Harvesting or scaring locusts}

Mechanical harvesting of locusts for food or feed is an option, but can only be practised during outbreaks, upsurges, and plagues, because only then so they form hopper bands and swarms. The cold-blooded adult insects are collected in the morning or during the night as they are rather immobile in cold temperatures. Before take-off, they must warm themselves at sunrise by basking in the sun.

In Madagascar, adults of the migratory locust are eaten (Van Itterbeeck et al., 2019). During upsurges (such as the one from 2014 to 2016), they are sometimes harvested by pulling big sheets over the vegetation. Only the adults (winged ones) are collected, then put in boiling water and dried in the sun often on roads. These are used for pigs and poultry. The best ones are selected for human consumption (Decary, 1937).

During the upsurge of 2019 to 2021 (FAO, 2021a) in the Horn of Africa, the Arabian Peninsula and the Indo-Pakistan border, attempts were made to harvest the locusts. A project in Pakistan, concerned about the environmental impact of pesticides, offered farmers US\$ 0.125 per $\mathrm{kg}$ of locusts collected at night; news article by Khan (2020). The insects are then turned into chicken feed by animal feed mills or used as food (Samejo et al., 2021). In Nepal, they chase the locusts making loud noises (using kitchen utensils), or smoke, or capture them in nets (Xinhua, 2020). Farmers received US\$ 1.65 per $\mathrm{kg}$ from the rural municipality for handing in the captured locusts. It is not certain what then happens to them. An organisation in Kenya was paying farmers US\$ 0.45 per $\mathrm{kg}$ of the insects, according a news report by Reuters (Ratner, 2021). The locusts are collected at night by torchlight when they are resting on shrubs and trees. They are then crushed and dried, and afterwards milled and processed into powder, which is used in animal feed or as an organic fertiliser. 


\section{Can we suppress locust upsurges by using them as food or feed?}

Samejo et al. (2021) reported the efforts made by people from 10 villages in Pakistan to harvest the desert locust: for 4 days they captured $1,275 \mathrm{~kg}$ from a swarm of $5 \mathrm{~km}^{2}$. The density of a desert locust swarm on the ground is on average about $50 / \mathrm{m}^{2}\left(20\right.$ to $\left.120+/ \mathrm{m}^{2}\right)$, which means $500,000(200,000-1,200,000)$ adults per ha (Symmons and Cressman, 2001), weighing about $1000(400-2,400) \mathrm{kg}(2 \mathrm{~g} /$ locust). Calculating from this $5 \mathrm{~km}^{2}(=500 \mathrm{ha}) \mathrm{swarm}$, the number was 250 (100-600) million adults, weighing 500,000 $(200,000-1,200,000) \mathrm{kg}$. So, the $1,275 \mathrm{~kg}$ harvested was only $0.3 \%(0.6-0.1 \%)$ of the population of this swarm. The authors concluded that the damage caused by the resulting hoppers from this swarm was lower than in other areas. However, given that the population was barely reduced by the harvesting effort, it is unlikely that this would have had any impact.

To keep a locust population stable, it is possible to calculate what percentage of the population need to be controlled at different multiplication rates (how many viable locusts can be produced by one female in a single generation). With a multiplication rate of 2, 5, 10 and 20, you need to destroy 50, 80, 90 and $95 \%$ of the population (Van Huis, 1994). At high multiplication rates, and it can be as high as 20 (Symmons and Cressman, 2001), this is an almost impossible task. Finding and killing the locusts may seem easy, but there are differences of opinion as to when to intervene (Van Huis et al., 2007). In addition to that, there are many challenges: (1) finding the locusts in the immense and remote areas of Africa and Asia is extremely difficult; (2) the areas are often difficult to access, given the topography and lack of security; (3) it is a logistical nightmare because you need the vehicles, planes, and pesticides in the right spot in areas with poor infrastructure (roads, communication and water); and (4) the spraying itself is difficult, because with the common ultra-low-volume technique you need to demarcate blocks with the highest concentration of locusts (Symmons, 1994). If harvesting, not spraying is the intention, then the problems can be multiplied manyfold.

Furthermore, it might not be a good idea to eat the locusts as it may not be clear whether they have been treated with pesticides. If a swarm arrives, it may have been treated before and thus contain a sublethal dose of pesticides. This is because in the whole distribution range of the desert locust the official policy is to control them with pesticides. The danger of poisoning will be less serious if locusts are treated with mycopesticides (Zimmermann, 2007) or growth regulators (FAO, 2014).
The Bombay locust is both an important pest and a popular food item. It seems that the outbreak from 1961 to 1963 was brought about by forest clearing and cereal production (Le Gall et al., 2019). The claim that the harvesting of the Bombay locust in Thailand for consumption was a successful control strategy (Hanboonsong, 2010) could not be substantiated with figures. Instead it seems that the locust in Thailand may be affected by a fungus that kills off large parts of the population (Haskell, 1971; Samšiňáková and Purrini, 1986).

However, the harvesting of edible locusts could be considered a strategy in environmental sensitive areas when pesticides would have an undesirable effect on the biodiversity. For example, the red locust often occurs in ecological sensitive areas such as wetlands. It would be comparable to the impact of birds on the population buildup. It may be considered as a crop protection strategy in areas where people are available. Strategies should be devised to process and conserve locusts for long periods.

\section{Conclusions}

Harvesting of the desert locust for food and feed should be considered as an opportunity during upsurges or plagues. It may help save a farmer's crop. Other possibilities for local crop protection include scaring the locusts with noise and smoke. However, it will have hardly any impact on the population during upsurges or plagues, considering the small percentage of the population that can feasibly be physically collected or destroyed.

\section{References}

Cheseto, X., Kuate, S.P., Tchouassi, D.P., Ndung'u, M., Teal, P.E.A. and Torto, B., 2015. Potential of the desert locust Schistocerca gregaria (Orthoptera: Acrididae) as an unconventional source of dietary and therapeutic sterols. PLoS ONE 10: e0127171. https:// doi.org/10.1371/journal.pone.0127171

Decary, R., 1937. L'entomophagie chez les indigènes de Madagascar. Bulletin de la Société Entomologique de France. Juin 9, 1937, pp. 168-171.

Dobson, H.M., 2001. Desert locust guidelines: control. Food and Agriculture Organization of the United Nations, Rome, Italy. Available at: http://www.fao.org/ag/locusts/common/ecg/347_ en_DLG4e.pdf.

Food and Agriculture Organization of the United Nations (FAO), 2014. Evaluation of field trials data on the efficacy and selectivity of insecticides on locusts and grasshoppers. Report to FAO by the Pesticide Referee Group $10^{\text {th }}$ meeting. December 10-12, 2014. Gammarth, Tunisia, 66 pp. Available at: http://www.fao.org/3/ bu337e/bu337e.pdf. 
Food and Agriculture Organization of the United Nations (FAO), 2021a. Current upsurge (2019-2021). Locust watch, FAO, Rome, Italy. Available at: http://www.fao.org/ag/locusts/en/info/2094/ index.html

Food and Agriculture Organization of the United Nations (FAO), 2021b. Frequently asked questions (FAQs) about locusts. Locust watch, FAO, Rome, Italy. Available at: http://www.fao.org/ag/locusts/ en/info/info/faq/index.html.

Hanboonsong, Y., 2010. Edible insects and associated food habits in Thailand. In: Durst, P.B., Johnson, D.V., Leslie, R.N. and Shono, K. (eds.) Forest insects as food: humans bite back. Proceedings of a workshop on Asia-Pacific resources and their potential for development. 19-21 February, 2008. Chiang Mai, Thailand, pp. 173-182. FAO Regional Office for Asia and the Pacific, Bangkok, Thailand. Available at: http://www.fao.org/3/i1380e/i1380e00.pdf.

Haskell, P.T., 1971. International locust research and control. Journal of the Royal Society of Arts 119: 249-263.

Khan, R.S., 2020. Pakistan's solution to the locust invasion? Turn the pests into chicken feed. Scroll-in, May 28, 2020. Available at: https:// scroll.in/article/963175/pakistans-solution-to-the-locust-invasionis-to-turn-the-pests-into-chicken-feed.

Kinyuru, J.N., 2020. Nutrient content and lipid characteristics of desert locust (Scistoscerca gregaria) swarm in Kenya. International Journal of Tropical Insect Science. https://doi.org/10.1007/s42690020-00308-3

Lanfranchi, G.B., 2005. Minilivestock consumption in the ancient near east: the case of locusts. In: Paoletti, M.G. (ed.) In: Paoletti, M.G. (ed.) Ecological implications of minilivestock: potential of insects, rodents, frogs and snails. Science Publishers, Inc., Enfield, NH, USA, pp. 163-174.

Le Gall, M., Overson, R. and Cease, A., 2019. A global review on locusts (Orthoptera: Acrididae) and their interactions with livestock grazing practices. Frontiers in Ecology and Evolution 7: 263. https:// doi.org/10.3389/fevo.2019.00263

Lockwood, J.A., 2004. Locust: the devastating rise and disappearance of the insect that shaped the American frontier. Basic Books, New York, NY, USA.

Lysakov, A., Grinchenko, V., Molchanov, A. and Devederkin, I., 2019. Effect of ultra-bright led light for locust plague control. Engineering for Rural Development. May 22-24, Jelgava, Latvia, pp. 630-634. https://doi.org/10.22616/erdev2019.18.n353

Price, R.E. and Brown, H.D., 2000. A century of locust control in South Africa. In: Cheke, R.A., Rosenberg, L.J. and Kieser, M.E. (eds.) Workshop on research priorities for migrant pests of agriculture in Southern Africa. Plant Protection Research Institute, Pretoria, South Africa, 24-26 March 1999. Available at: https://gala.gre.ac.uk/ id/eprint/12211/1/12211_Cheke_Workshop\%20on\%20research\%20 priorities\%20(book)\%202000.pdf\#page $=51$.

Ratner, B., 2021. Farmers fight back: making animal feed from a locust plague. Available at: https://widerimage.reuters.com/story/farmersfight-back-making-animal-feed-from-a-locust-plague.
Samejo, A.A., Sultana, R., Kumar, S. and Soomro, S., 2021. Could entomophagy be an effective mitigation measure in desert locust management? Agronomy 11: 455. https://doi.org/10.3390/ agronomy11030455

Samšiňáková, A. and Purrini, K., 1986. Über eine natürliche Infektion der Heuschrecke, Patanga succincta durch den Pilz Metarhizium anisopliae in Thailand. Journal of Applied Entomology 102: 273-277. https://doi.org/10.1111/j.1439-0418.1986.tb00922.x

Stride, B., Shah, A. and Sadeed, S.M., 2003. Recent history of Moroccan locust control and implementation of mechanical control methods in northern Afghanistan. International Journal of Pest Management 49: 265-270. https://doi.org/10.1080/0967087031000101098

Symmons, P.M., 1994. Can we combat the desert locust successfully? In: Van Huis, A. (ed.) Proceedings of the seminar desert locust control with existing techniques: an evaluation of strategies. Wageningen UR, Wageningen, the Netherlands, pp. 63-68.

Symmons, P.M. and Cressman, K., 2001. Desert locust guidelines. Biology and behaviour. FAO, Rome, Italy. Available at: http://www. fao.org/ag/LOCUSTS/common/ecg/347_en_DLG1e.pdf.

Van Huis, A., 1994. Can we combat the desert locust successfully? In: Van Huis, A. (ed.) Proceedings of the seminar desert locust control with existing techniques: an evaluation of strategies. Wageningen UR, Wageningen, the Netherlands, pp. 11-17.

Van Huis, A., 2020. Insect pests as food and feed. Journal of Insects as Food and Feed 6: 327-331. https://doi.org/10.3920/JIFF2020.x004

Van Huis, A., Cressman, K. and Magor, J.I., 2007. Preventing desert locust plagues: optimizing management interventions. Entomologia Experimentalis et Applicata 122: 191-214. https://doi.org/10.1111/ j.1570-7458.2006.00517.x

Van Itterbeeck, J., Rakotomalala Andrianavalona, I.N., Rajemison, F.I., Rakotondrasoa, J.F., Ralantoarinaivo, V.R., Hugel, S. and Fisher, B.L., 2019. Diversity and use of edible grasshoppers, locusts, crickets, and katydids (Orthoptera) in Madagascar. Foods 8: 666. https:// doi.org/10.3390/foods 8120666

Xinhua, 2020. Nepali municipal governments, farmers make efforts to fight locust invasion. Xinhuanet, 14 July 2020. Available at: http:// www.xinhuanet.com/english/2020-07/14/c_139212263.htm.

Yao, M., Liu, M., Huang, L., Zhao, J. and Zhou, Q., 2009a. Application of near infrared laser in controlling locust. Third International Symposium on Intelligent Information Technology Application. November 21-22, 2009. NanChang, China, pp. 304-307.

Yao, M., Liu, M., Zhao, J. and Zhou, Q., 2009b. Irradiation effect of continuous diode laser on locusts and host plants. Proceedings of the 2009 International Symposium on Web Information Systems and Applications (WISA'09). NanChang, China, pp. 230-233. Available at: http://citeseerx.ist.psu.edu/viewdoc/download?doi=10.1.1.487 $.9162 \&$ rep $=$ rep $1 \&$ type $=$ pdf.

Zimmermann, G., 2007. Review on safety of the entomopathogenic fungus Metarhizium anisopliae. Biocontrol Science and Technology 17: 879-920. https://doi.org/10.1080/09583150701593963 